\title{
Black and Minority Ethnic (BAME) Alliance Against COVID-19: One Step Forward
}

\author{
Mohamed H. Ahmed ${ }^{1}$ (C)
}

Received: 29 May 2020 / Revised: 28 July 2020 / Accepted: 29 July 2020 / Published online: 12 August 2020

(C) W. Montague Cobb-NMA Health Institute 2020

\begin{abstract}
During the COVID-19 pandemic, the data of Department of Health in United Kingdom (UK) showed an increase mortality and morbidity among the Black and Minority Ethnic (BAME) population. This high mortality can be due to social factors, genetic and immunological factors. Metabolic factors like high prevalence of diabetes, obesity, metabolic syndrome and hypertension were also found to contribute to the increased risk of COVID-19 infection in BAME population. In addition, a large number of BAME population are working in jobs that involve regular and daily contact with public, and this may increase risk of encountering COVID-19 infection. Therefore, future research should address all these factors and generate the correct health policy that will allow us to combat the danger of COVID-19. We recommend the establishment of BAME alliance against COVID-19 in order to improve occupational risks and hazards, adequate income protection, culturally and linguistically appropriate public health communications and decreasing barriers in accessing healthcare. The BAME alliance will initially focus on (i) development of central system to record data about COVID-19 patients from BAME population (ii) involvement of healthcare professionals and researchers from ethnic minorities and (iii) multidisciplinary and inter-institution collaboration; for example, civil engineers and architects need to think about house design and ventilation that decrease risk of COVID-19 especially in BAME populations.
\end{abstract}

Keywords COVID-19 $\cdot$ BAME $\cdot$ Social factors $\cdot$ Diabetes $\cdot$ Hypertension

\section{Introduction}

The definition of ethnicity is complex and not easy as it can involve the commonalities within a group or as differences from 'other' groups [1]. Burchard et al. defined ethnicity as 'a related but broader construct encompassing culture, tradition, religion and shared heritage', while they define race as 'a socio-political construct and classification system based on the geographic origin of a person's ancestry' [2]. The variations in genetic mapping, immune system, behaviour and metabolic disorders may render certain ethnic group more suceptible to a certain disease [3]. For example, COVOID-19 was associated an increased morbidity and mortality among BAME population $[3,4]$. The high

Mohamed H. Ahmed

elziber@yahoo.com; Mohamed.Hassan-Ahmed@mkuh.nhs.uk

1 Department of Medicine and HIV Metabolic Clinic, Milton Keynes University Hospital NHS Foundation Trust, Eaglestone, Milton Keynes, Buckinghamshire, UK prevalence of diabetes, metabolic syndrome, obesity and hypertension in BAME population was suggested as an additional risk for COVID-19 infection [3-5]. Different social factors can be included as BAME represent almost all ethnic groups from around the world.

Deprivation and poverty are well-established factors associated with an increased risk of COVID-19 mortality. Low financial income was reported in Black population and also in some populations from Indian subcontinent like Pakistani, Bangladeshi and Indian populations [3-6]. During the COVID-19 pandemic, some individuals from BAME communities were hourly wage earners, they have no paid leave or vacation days that they can take; therefore, they left with option to continue to work in order to continue to earn income. It is possible to suggest that these individuals could be at risk of carrying infection from one place to other, especially in the view of the housing condition. In the view of the poverty and low income, it is not surprising that some members of the BAME population are also more likely to live in overcrowded and multi-generational households $[4,5]$. These factors pose a huge impediment for social distancing. Importantly, a large 
number of BAME population are working in jobs that involve regular and daily contact with public like bus drivers, taxi drivers and security guards [3-6].

It is worth mentioning that many BAME population are living in interconnected communities, so implementation of social distancing, not shaking hands and not engaging in face to face communications were slowly implemented at beginning of the pandemic of COVID-19 [4]. Importantly, the panic buying behaviour has also in part increased chance of transmission in communities living with their extended families. One important question is whether BAME health workers were exposed to the infection in their communities or whether they encounter it in hospitals or they have been exposed to high viral load due to exposure in both communities and hospitals.

Social factors have huge impact in behaviours and attitudes of the individuals especially during pandemic, and this can be attributed to cultures and traditions within that societies. Some individuals from BAME populations have shown optimism bias, which mean that they underestimated the danger of COVID-19 and ignored the public health warnings [7]. This can be attributed to the fact that pandemic can be associated with an increase in level of ethnocentrism, racism and fear [8]. However, a few weeks after the onset of pandemic in the UK, we witnessed greater cooperation and unity among different communities and religious groups in order to help to decrease the infection rate. In addition, the BAME populations in the UK have not suffered discrimination in terms of accessing the National Health Service (NHS) during COVID-19 pandemic. The UK government published survey about housing, this showed that White British households are the least to be affected by overcrowding (2\%), while overcrowding affected $15 \%$ of Black African households, $30 \%$ of Bangladeshi households, $16 \%$ Pakistani households, $7 \%$ Chinese households and $7 \%$ of Indian households [9]. Several studies from previous influenza pandemic showed that BAME population are also more likely to be socioeconomically disadvantaged than white communities. For instance, Haroon et al. showed that during the 2009/2010 influenza pandemic, socioeconomic deprivation and ethnicity may have an influence in health seeking behaviour [10]. Zhoe et al. (2015) recommended the importance of quick screening for high-risk individuals for severe influenza, as they mentioned that highest risk group for mortality during the 2009/2010 influenza pandemic were those of Pakistani ethnicity followed by non-White ethnicity in comparison with White populations [11]. In addition, systematic review by Tricco et al. showed that hospitalizations were significantly higher among ethnic minorities in comparison with nonethnic minorities during the influenza pandemic [12]. Therefore, it is plausible to suggest that if actions were taken at the time of influenza pandemic in $2009 / 2010$, these actions in part may have decreased the highest mortality and mortality in BAME population during the COVID-19 pandemic in 2020. Non-English speakers may find difficulty in using the emergency services provided by the NHS. It is also important to assess the need to decrease cultural barriers, which may prevent BAME from benefiting from the full services provided by the NHS. In addition, racial discrimination was also shown to be associated with diabetes and hypertension [13-16]. Significant exposure to stress can decrease immunity, and stress in BAME population can be attributed to social isolation, lack of spiritual activities, concern about wellbeing and health of families in the UK and overseas, financial constraints and the fading of resilience especially with longer duration of the lockdown [17]. The use of alternative remedies to protect and treat COVID-19 was also practised during the pandemic [17]. These factors have important role and complex interaction with the psychological wellbeing of the individuals which can ultimately affect their immune system and behaviours in responding to public health warnings.

\section{Evidence from Systematic Reviews, Large Studies and Recommendations About BAME and COVID-19}

There are limited studies about BAME and COVID-19. However, systemic review by Pan et al. suggested that BAME individuals are at more risk of COVID-19 than White individuals and may develop more complications [18]. Aldridge et al. collected mortality data from NHS England during COVID-19. Their data showed that highest rate of death was seen among Indian (492 deaths) and Black Caribbean (460 deaths) groups. Furthermore, when adjustment for region was used, this showed less death reported in White British and White Irish but increased risk of death for Black African, Black Caribbean, Pakistani, Bangladeshi and Indian minority ethnic groups [19].Therefore, the NHS advised risk assessment for staff in front line of BAME origin (risk of encountering COVID-19 infection), and suggestion was made for risk assessment for dentists from BAME origin [20]. This of considerable benefits as a recent cross-sectional study showed that BAME workforce are routinely involved in front line work in the NHS and anxiety level was very high [21]. Recently, it was also recommended that more representation of BAME in the medical education system is needed [22]. This will help to direct research and teaching according to the need of the community [23]. Another recommendation is that the NHS health checks should start at the age of 25 years old for BAME population, as it is currently offered for people aged 40-74 years. This may allow early detection and treatment of chronic conditions [24]. The rationale behind lowering the age of healthy check is that chronic disease is a 
modifiable risk factor and this health check is normally done by primary care physicians. This will require an assessment of the total number of individuals who need assessment and whether the current numbers of family physicians can meet the demand for such health check. Further research will be needed to establish whether there is scientific evidence for lowering the age of health checks and whether such initiative will decrease morbidity and mortality among BAME population. It is not yet established how much will be the cost for primary healthcare. An important point to consider, even after you establish the diagnosis of such chronic conditions, we will need to establish how the NHS will be able to deal with such influx of patients. On the other hand, if such move proves to be useful, it could be adopted worldwide. In terms of community education, it was also recommended that places of worship can be health promotion spaces for faith-based BAME communities [25]. Importantly, the involvement of community and religious leaders may also help in coordinating efforts to support measures for effective control, easy access to communities and appropriate implementation of the test, track and trace programme. The second lockdown of COVID-19 in Leicester (city in England with high representation of BAME population) may suggest the need for more research and preventative measures and policies [26, 27]. The second lockdown highlighted the need for more coordination of efforts in order to combat the danger of COVID-19. In Table 1, we have summarized different social, biochemical, genetic and metabolic factors that can be involved in increasing risk of encountering COVID-19 in BAME populations.

\section{The Way Forward for BAME Alliance Against COVID-19}

The complex interaction between ethnicity, poverty, genetic factors, diabetes, dyslipidaemia, obesity, hypertension and COVID-19 suggests the need for more coordinated actions and research and the need to understand why some ethnic groups experience greater risk. Furthermore, there is an urgent need to decrease causes of death among BAME populations. Perhaps the government and politicians will need to think about actions that will help BAME communities by improving occupational risks and hazards, adequate income protection and culturally and linguistically appropriate public health communications and decreasing barriers in accessing healthcare. These great efforts can be facilitated and coordinated by the BAME alliance against COVID-19. The main long-term functions of BAME alliance are summarized in Table 2. The main three immediate aims of the BAME alliance against COVID-19 is to assist (i) development of central system to record data about COVID-19 patients from BAME population, (ii)
Table 1 Showing summary of different social, biochemical, genetic and metabolic factors that can be involved in increasing risk of encountering COVID-19 in BAME populations

\begin{tabular}{|c|c|c|}
\hline Factor & Explanation & Reference \\
\hline Social factors & $\begin{array}{l}\text { Deprivation, poverty, low } \\
\text { income, overcrowded } \\
\text { houses, working in jobs } \\
\text { with direct contact with } \\
\text { public, panic buying and } \\
\text { food insecurity, social } \\
\text { isolation, racism, lack of } \\
\text { resilience and stress }\end{array}$ & {$[28-30]$} \\
\hline Metabolic factors & $\begin{array}{l}\text { High prevalence of metabolic } \\
\text { syndrome, hypertension, } \\
\text { dyslipidaemia, obesity and } \\
\text { type } 2 \text { diabetes was noticed } \\
\text { in BAME population. All } \\
\text { these conditions were } \\
\text { noted to be associated with } \\
\text { high risk for COVID-19 }\end{array}$ & [31-33] \\
\hline Genetic factors & $\begin{array}{l}\text { High tendency for cytokine } \\
\text { storm and thromboembolic } \\
\text { phenomena in BAME } \\
\text { population. These are } \\
\text { important features in } \\
\text { pathogenesis of } \\
\text { COVID-19 }\end{array}$ & [34-38] \\
\hline $\begin{array}{l}\text { Chronic infection like TB } \\
\text { and HIV and chronic } \\
\text { medical conditions like } \\
\text { sickle cell anaemia }\end{array}$ & $\begin{array}{l}\text { These conditions may be } \\
\text { found in small number of } \\
\text { BME. Patients with } \\
\text { inherited causes of } \\
\text { anaemia like sickle cell } \\
\text { anaemia were advised } \\
\text { about high risk of } \\
\text { encountering COVID-19 } \\
\text { infection }\end{array}$ & [39-42] \\
\hline Low vitamin $\mathrm{D}$ & $\begin{array}{l}\text { Low vitamin D may be } \\
\text { associated with COVID-19 } \\
\text { in BAME population but } \\
\text { no potential link between } \\
\text { vitamin D concentrations } \\
\text { and risk of COVID-19 in- } \\
\text { fection }\end{array}$ & {$[43,44]$} \\
\hline Psychological factors & $\begin{array}{l}\text { Mental stress and } \\
\text { psychosocial factors like } \\
\text { low cognitive function can } \\
\text { be associated with hospital } \\
\text { admission with COVID-19 }\end{array}$ & {$[45,46]$} \\
\hline
\end{tabular}

involvement of healthcare professionals and researchers from ethnic minorities, (iii) multidisciplinary and interinstitution collaboration; for example, civil engineers and architects need to think about house design and ventilation that decrease risk of COVID-19 especially in BAME populations. Indeed, further research and debate are needed in case of implementation of BAME alliance to establish whether such body will be working as an independent unit or part of already established socialized medical structure 
Table 2 The main long-term functions of BAME alliance

1. Improving and decreasing the gap in psychosocial inequalities

2. Improving access to health system and addressing metabolic factors like obesity, hypertension, diabetes and metabolic syndrome

3. NHS health checks should start at age 25 for BAME population

4. More representation of BAME in medical education system in medical schools and university hospitals

5. Health education and promotion for community

6. Better surveillance and management of chronic disease

7. Increasing cultural awareness in order to avoid second wave of COVID-19

8. Training of community and religious leaders in preventative measures against COVID-19

9. Short- and long-term research in understanding the impact of COVID-19 in BAME communities

10. Improving housing condition and ventilation

to do their research and interventions or acting as a watch dog agency pointing out where attention needs to be focused. Figure 1 gives brief summary for the proposed different academic and governmental bodies involved in the BAME alliance against COVID-19.

\section{Conclusions}

The BAME alliance can be the first step toward addressing solutions for BAME and COVID-19 as suggested in Table 2. However, achieving these goals will need significant efforts and substantial funding and may take many years to achieve. Social inequalities will be challenging task and may take at least one or two decades to see the benefits of investment in such initiative. Investment in accessibility for university education and technical colleges training will provide opportunities for young individuals from BAME population to find jobs in different aspects of life. Accessibility to higher education can also be improved by expanding the system of quota or providing scholarship for BAME or offering cheap tuition fees for studying in the technical colleges. It is possible that BAME alliance may also offer a platform for discussion and debate about how to develop a more innovative mechanisms that will help decrease social gaps. Investment in education will help in investment in English language, and in case of non-English speakers, there is a need for investment in translation services in the health system. Investment in education and English language may in part help in integration and decrease in cultural barriers. It is worth mentioning that there
Fig. 1 Brief summary for the proposed different academic and governmental bodies involved in the BAME alliance against COVID-19

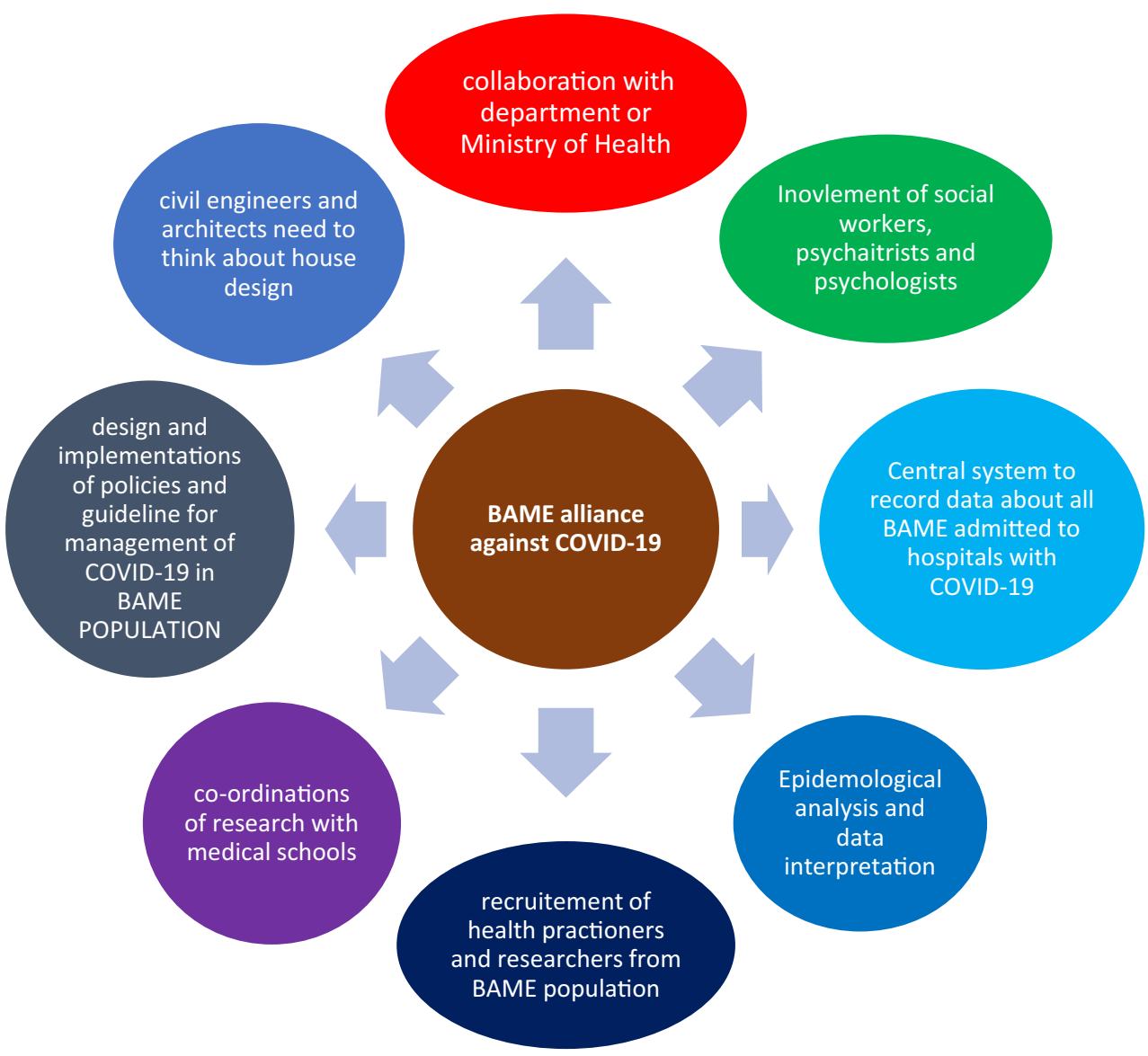


are different programmes in the UK which also share similar objectives, but in my own opinion, these programmes can be more effective than before as COVID-19 pandemic brought sense of unity and appreciations for all these community welfare programmes.

The overcrowding in housing can be very challenging and difficult to resolve. This is due to the fact that some BAME families are extended and interconnected. In addition, more debate and research are also needed to address how elderly BAME individuals can benefit from utilizing care homes or other alternative facilities in order to reduce overcrowded housing. In some of BAME populations, sending parents to elderly care homes may stand against common religious teaching, custom and tradition. Therefore, the COVID-19 pandemic could be the driver for the changes in the design and structure of housing and cities. These changes could be in similar benefits of Garden cities, built after the Second World War, which addressed the need to prevent spread of diseases associated with design of high-quality housing. Several reports suggested the need for reform in the design of houses and cities after COVID-19 pandemic [47-50]. Horizontal expansion in housing can be costly for government, but civil engineers and architects may have the best say about vertical expansion for housing structure. Perhaps this may allow large and extended families to live together in four or three-storey house design with adequate natural ventilation. This may also decrease the burden on residential care homes, as some families among BAME population regard looking after elderly parents as religious duties. Perhaps it is true that in our history as humans in the face of the earth, we never give up in the struggle against different diseases and pandemics and this is why when we look back for our ancestor's achievements, we found a lot of joy and encouragement as they never gave up.

Code Availability Not applicable.

Author's Contributions The manuscript was written by MH Ahmed.

Data Availability Not applicable.

\section{Compliance with Ethical Standards}

Conflicts of Interest The author declares that he has no conflict of interest.

Ethics Approval This article does not contain any studies with human participants or animals performed by the author.

Consent to Participate Not applicable.

Consent for Publication The author gives full consent for publication of this article to the Journal of Racial and Ethnic Health Disparities.

\section{References}

1. https://www.understandingsociety.ac.uk/sites/default/files/ downloads/working-papers/2008-02.pdf. Accessed 23/5/2020.

2. Burchard EG, Ziv E, Coyle N, Gomez SL, Tang H, Karter AJ, et al. The importance of race and ethnic background in biomedical research and clinical practice. N Engl J Med. 2003;348(12):1170-5.

3. Khunti K, Singh AK, Pareek M, Hanif W. Is ethnicity linked to incidence or outcomes of covid-19? BMJ. 2020;369:m1548. https://doi.org/10.1136/bmj.m1548.

4. Pareek M, Bangash MN, Pareek N, Pan D, Sze S, Minhas JS, et al. Ethnicity and COVID-19: an urgent public health research priority. Lancet. 2020;395(10234):1421-2. https://doi.org/10.1016/S01406736(20)30922-3.

5. Chudasama YV, Gillies CL, Zaccardi F, Coles B, Davies MJ, Seidu S, et al. Impact of COVID-19 on routine care for chronic diseases: a global survey of views from healthcare professionals [published online ahead of print, 2020 Jun 23]. Diabetes Metab Syndr. 2020;14(5):965-7. https://doi.org/10.1016/j.dsx.2020.06.042.

6. Abuelgasim E, Saw LJ, Shirke M, Zeinah M, Harky A. COVID-19: unique public health issues facing Black, Asian and minority ethnic communities. Curr Probl Cardiol. 2020;45(8):100621. https://doi. org/10.1016/j.cpcardiol.2020.100621.

7. Sharot T. The optimism bias. Time. 2011;177(23):40-6.

8. Schaller M, Neuberg SL. Danger, disease, and the nature of prejudice(s). Adv Exp Soc Psychol. 2012). ISSN 0065-2601;46:1-54. https://doi.org/10.1016/B978-0-12-394281-4.00001-5.

9. UK government. Overcrowded households. Available from: https:// www.ethnicity-facts UK government. Overcrowded households. Available from:https://www.ethnicity-facts-figures.service.gov.uk/ housing/housing-conditions/overcrowded-households/2.2. Accessed 26.07.2020.

10. Haroon SM, Barbosa GP, Saunders PJ. The determinants of healthseeking behaviour during the $\mathrm{A} / \mathrm{H} 1 \mathrm{~N} 1$ influenza pandemic: an ecological study. J Public Health (Oxf). 2011;33(4):503-10. https:// doi.org/10.1093/pubmed/fdr029.

11. Zhao H, Harris RJ, Ellis J, Pebody RG. Ethnicity, deprivation and mortality due to 2009 pandemic influenza A(H1N1) in England during the 2009/2010 pandemic and the first post-pandemic season. Epidemiol Infect. 2015;143(16):3375-83. https://doi.org/10.1017/ S0950268815000576.

12. Tricco AC, Lillie E, Soobiah C, Perrier L, Straus SE. Impact of H1N1 on socially disadvantaged populations: summary of a systematic review. Influenza Respir Viruses. 2013;7(Suppl 2):54-8. https://doi.org/10.1111/irv.12082.

13. Barajas CB, Jones SCT, Milam AJ, Thorpe RJ Jr, Gaskin DJ, LaVeist TA, et al. Coping, discrimination, and physical health conditions among predominantly poor, urban African Americans: implications for community-level health services. J Community Health. 2019;44(5):954-62. https://doi.org/10.1007/s10900-01900650-9.

14. Williams DR, Lawrence JA, Davis BA. Racism and health: evidence and needed research. Annu Rev Public Health. 2019;40: 105-25. https://doi.org/10.1146/annurev-publhealth-040218043750 .

15. Sittner KJ, Greenfield BL, Walls ML. Microaggressions, diabetes distress, and self-care behaviors in a sample of American Indian adults with type 2 diabetes. J Behav Med. 2018;41(1):122-9. https://doi.org/10.1007/s10865-017-9898-z.

16. Michaels EK, Reeves AN, Thomas MD, et al. Everyday racial discrimination and hypertension among midlife African American women: disentangling the role of active coping dispositions versus active coping behaviors. Int J Environ Res Public Health. 2019;16(23):4759. Published 2019 Nov 27. https://doi.org/10. 3390/ijerph16234759. 
17. Bavel JJV, Baicker K, Boggio PS, Capraro V, Cichocka A, Cikara $\mathrm{M}$, et al. Using social and behavioural science to support COVID19 pandemic response. Nat Hum Behav. 2020;4(5):460-71. https:// doi.org/10.1038/s41562-020-0884-z.

18. Pan D, Sze S, Minhas JS, et al. The impact of ethnicity on clinical outcomes in COVID-19: a systematic review. EClinicalMedicine. 2020;23:100404. Published 2020 Jun 3. https://doi.org/10.1016/j. eclinm.2020.100404.

19. Aldridge RW, Lewer D, Katikireddi SV, et al. Black, Asian and Minority Ethnic groups in England are at increased risk of death from COVID-19: indirect standardisation of NHS mortality data. Wellcome Open Res. 2020;5:88 Published 2020 Jun 24.

20. Trivedy C, Mills I, Dhanoya O. The impact of the risk of COVID19 on Black, Asian and Minority Ethnic (BAME) members of the UK dental profession. Br Dent J. 2020;228(12):919-22. https://doi. org/10.1038/s41415-020-1781-6.

21. Moorthy A, Sankar TK. Emerging public health challenge in UK: perception and belief on increased COVID19 death among BAME healthcare workers [published online ahead of print, $2020 \mathrm{Jul}$ 3]. J Public Health (Oxf). 2020;fdaa096. https://doi.org/10.1093/ pubmed/fdaa096.

22. Lynch CA. Diversifying medical school education to represent BAME backgrounds. BMJ. 2020;370:m2745. Published 2020 Jul 10. https://doi.org/10.1136/bmj.m2745.

23. Ahmed MH. Analyzing the social aspects of the integrated program of field training, research, and rural development course, Faculty of Medicine, University of Gezira, Sudan. J Educ Health Promot. 2019;8:166. Published 2019 Sep 30. https://doi.org/10.4103/jehp. jehp 44118.

24. O'Dowd $\bar{A}$. NHS health checks should start at age 25 for BAME patients, MPs hear. BMJ. 2020;369:m2462. Published 2020 Jun 18. https://doi.org/10.1136/bmj.m2462.

25. Ali P. Places of worship can be health promotion spaces for faithbased black, Asian and minority ethnic (BAME) communities Evid Based Nurs. 2019; ebnurs-2019-103140. https://doi.org/10.1136/ ebnurs-2019-103140.

26. Nazareth J, Minhas JS, Jenkins DR, et al. Early lessons from a second COVID-19 lockdown in Leicester, UK [published online ahead of print, $2020 \mathrm{Jul}$ 2]. Lancet. 2020;S0140-6736(20)31490-2. https://doi.org/10.1016/S0140-6736(20)31490-2

27. Mahase E. Covid-19: Leicester placed under lockdown after spike in cases and hospital admissions. BMJ. 2020;369:m2635. Published 2020 Jun 30. https://doi.org/10.1136/bmj.m2635

28. ONS. Deaths involving COVID-19 by local area and socioeconomic deprivation: deaths occurring between 1 March and 17 April 2020: Office for National Statistics2020 [updated 1/05/2020; cited 2020 05/05/2020]. Available from: https://www.ons.gov.uk/ peoplepopulationandcommunity/birthsdeathsandmarriages/deaths/ bulletins/deathsinvolvingcovid19bylocalareasanddeprivation/ deathsoccurringbetween 1 marchand17april. Accessed 12-07-2020

29. GOV.UK. Overcrowded households 2018 [updated 27/04/2019. Available from: ethnicity-facts-figures.service.gov.uk/housing/ housing-conditions/overcrowded-households/latest. Accessed 1207-2020.

30. GOV.UK. Regional ethnic diversity 2018 [updated 11/07/2019. Available from: https://www.ethnicity-facts-figures.service.gov. uk/uk-population-by-ethnicity/national-and-regional-populations/ regional-ethnic-diversity/latest\#full-page-history. Accessed 12-072020.

31. Hartmann-Boyce J, Morris E, Goyder C, et al. Diabetes and COVID-19: risks, management, and learnings from other national disasters [published online ahead of print, 2020 Jun 16]. Diabetes Care. 2020;dc201192. https://doi.org/10.2337/dc20-1192.

32. Singh AK, Khunti K. Assessment of risk, severity, mortality, glycemic control and antidiabetic agents in patients with diabetes and COVID-19: a narrative review [published online ahead of print,
2020 Jun 11]. Diabetes Res Clin Pract. 2020;165:108266. https:// doi.org/10.1016/j.diabres.2020.108266.

33. Singh AK, Gillies CL, Singh R, et al. Prevalence of comorbidities and their association with mortality in patients with COVID-19: a systematic review and meta-analysis [published online ahead of print, 2020 Jun 23]. Diabetes Obes Metab. 2020. https://doi.org/ 10.1111/dom.14124.

34. Nedelec Y, Sanz J, Baharian G, Szpiech ZA, Pacis A, Dumaine A. Genetic ancestry and natural selection drive population differences in immune responses to pathogens. Cell. 2016;167(3):657-69. https://doi.org/10.1016/j.cell.2016.09.025.e21.

35. Paalani M, Lee JW, Haddad E, Tonstad S. Determinants of inflammatory markers in a bi- ethnic population. Ethn Dis. 2011;21(2): $142-9$

36. Whyte MB, Vas P, Heiss C, Feher MD. The contribution of diabetic micro-angiopathy to adverse outcomes in COVID-19. Diabetes Res Clin Pract. 2020;164:108217. https://doi.org/10.1016/j.diabres. 2020.108217.

37. Bikdeli B, Madhavan MV, Jimenez D, Chuich T, Dreyfus I, Driggin E, et al. COVID-19 and thrombotic or thromboembolic disease: implications for prevention, antithrombotic therapy, and follow-up: JACC state-of-the-art review. J Am Coll Cardiol. 2020;75(23):2950-73. https://doi.org/10.1016/j.jacc.2020.04.031.

38. Lemke G, Silverman GJ. Blood clots and TAM receptor signalling in COVID-19 pathogenesis. Nat Rev Immunol. 2020;20(7):395-6. https://doi.org/10.1038/s41577-020-0354-x.

39. Roy NBA, Telfer P, Eleftheriou P, de la Fuente J, Drasar E, Shah F. Protecting vulnerable patients with inherited anaemias from unnecessary death during the COVID-19 pandemic. Br J Haematol. 2020;189(4):635-9. https://doi.org/10.1111/bjh.16687.

40. Eborall H, Wobi F, Ellis K, et al. Integrated screening of migrants for multiple infectious diseases: qualitative study of a city-wide programme. EClinicalMedicine. 2020;21:100315. Published 2020 Apr 18. https://doi.org/10.1016/j.eclinm.2020.100315.

41. Härter G, Spinner CD, Roider J, Bickel M, Krznaric I, Grunwald S, et al. COVID-19 in people living with human immunodeficiency virus: a case series of 33 patients [published online ahead of print, 2020 May 11]. Infection. 2020:1-6. https://doi.org/10.1007/ s15010-020-01438-z.

42. Hargreaves S, Seedat F, Car J, et al. Screening for latent TB, HIV, and hepatitis $\mathrm{B} / \mathrm{C}$ in new migrants in a high prevalence area of London, UK: a cross-sectional study. BMC Infect Dis. 2014;14: 657. Published 2014 Dec 3. https://doi.org/10.1186/s12879-0140657-2.

43. Raisi-Estabragh Z, McCracken C, Bethell MS, et al. Greater risk of severe COVID-19 in Black, Asian and Minority Ethnic populations is not explained by cardiometabolic, socioeconomic or behavioural factors, or by $25(\mathrm{OH})$-vitamin D status: study of 1326 cases from the UK Biobank [published online ahead of print, 2020 Jun 19]. J Public Health (Oxf). 2020;fdaa095. https://doi.org/10.1093/ pubmed/fdaa095

44. Hastie CE, Mackay DF, Ho F, Celis-Morales CA, Katikireddi SV, Niedzwiedz CL, et al. Vitamin D concentrations and COVID-19 infection in UK Biobank [published online ahead of print, 2020 May 7]. Diabetes Metab Syndr. 2020;14(4):561-5. https://doi.org/ 10.1016/j.dsx.2020.04.050.

45. Batty GD, Deary IJ, Luciano M, Altschul DM, Kivimäki M, Gale CR. Psychosocial factors and hospitalisations for COVID-19: prospective cohort study based on a community sample [published online ahead of print, 2020 Jun 16]. Brain Behav Immun. 2020;S0889-1591(20)31309-X.

46. Lassale C, Gaye B, Hamer M, Gale CR, Batty GD. Ethnic disparities in hospitalisation for COVID-19 in England: the role of socioeconomic factors, mental health, and inflammatory and proinflammatory factors in a community-based cohort study [published online ahead of print, 2020 Jun 1]. Brain Behav Immun. 
2020;S0889-1591(20)31101-6. https://doi.org/10.1016/j.bbi.2020. 05.074

47. D'Alessandro D, Gola M, Appolloni L, et al. COVID-19 and living space challenge. Well-being and public health recommendations for a healthy, safe, and sustainable housing. Acta Biomed. 2020;91(9-S):61-75. Published 2020 Jul 20. https://doi.org/10. 23750/abm.v91i9-S.10115.

48. Capolongo S, Rebecchi A, Buffoli M, et al. COVID-19 and cities: from urban health strategies to the pandemic challenge. A Decalogue of Public Health opportunities. Acta Biomed.
2020;91(2):13-22. Published 2020 May 11. https://doi.org/10. 23750/abm.v91i2.9615.

49. https://www.architectsjournal.co.uk/opinion/how-will-housingdesign-and-placemaking-be-changed-by-covid-19/10046945. article. Accessed 28-7-2020.

50. https://architizer.com/blog/inspiration/industry/covid19-citydesign/. Accessed 28-7-2020.

Publisher's Note Springer Nature remains neutral with regard to jurisdictional claims in published maps and institutional affiliations. 